\title{
Literature Review: Pemanfaatan Sistem Informasi Cerdas Pertanian Berbasis Internet of Things (IoT)
}

\author{
Abdur Rouf ${ }^{1}$, Wahyudi Agustiono ${ }^{2}$ \\ ${ }^{1,2}$ Fakultas Teknik, Universitas Trunojoyo Madura \\ e-mail: ${ }^{1} 170441100037 @$ student.trunojoyo.ac.id; ${ }^{2}$ wahyudi.agustiono@trunojoyo.ac.id.
}

\begin{abstract}
Abstrak
Pertanian mempunyai peran yang begitu penting di dalam proses keberlangsungan hidup manusia. Di Indonesia, sebagian besar penduduk atau masyarakatnya bekerja di bidang pertanian. Penerapan IoT akan sangat masif digunakan untuk merealisasikan sistem pertanian cerdas (smart farming). Dikarenakan populernya penerapan IoT di bidang pertanian saat ini, maka tujuan dari literature review ini yaitu untuk menjelaskan tentang penggunaan Internet of Things (IoT) di bidang pertanian khususnya dalam merealisasikan sistem informasi cerdas pertanian. Terdapat hasil bahwa IoT banyak digunakan di pertanian hortikultura dengan metode pengembangan prototyping. Variabel penelitian paling banyak diteliti pada kelembapan, dan suhu baik yang di tanah, air, maupun udara. Platform yang populer digunakan yaitu website berbasis IoT.
\end{abstract}

Kata kunci: sistem informasi cerdas, pertanian, internet of things, literature reviews

\begin{abstract}
Agriculture has such an important role in the process of human survival. In Indonesia, most of the population or people work in agriculture. The application of IoT will be massively used to realize smart farming systems. Due to the popular application of IoT in agriculture today, the purpose of this literature review is to explain the use of the Internet of Things (IoT) in agriculture, especially in realizing smart agricultural information systems. It is found that IoT is widely used in horticultural agriculture by prototyping development methods. Research variables are most studied on humidity, and temperature in soil, water, and air. The most popular platform used is IoT-based websites.
\end{abstract}

Keywords: smart information systems, agriculture, internet of things, literature reviews

\section{PENDAHULUAN}

Pertanian mempunyai peran yang begitu penting di dalam proses keberlangsungan hidup manusia [1]. Di Indonesia, sebagian besar penduduk atau masyarakatnya bekerja di bidang pertanian [2]. Akan tetapi, proses mengolah dan menjaga lahan pertanian masih dilakukan dengan cara lama oleh tenaga manusia [3]. Proses pengelolaan lahan pertanian yang masih bersifat manual akan sangat mempengaruhi terhadap hasil panen [4].

Perkembangan Teknologi Informasi dan Komunikasi yang terjadi saat ini, berlangsung dengan pesat dan sudah banyak digunakan di berbagai bidang kehidupan seperti dunia industri, bidang kesehatan, pertahanan, pengelolaan pertanian dan yang 
lainnya [5]. Di bidang pertanian, manfaat dari adanya teknologi informasi dan komunikasi (TIK) sudah banyak memberikan kemudahan dalam kegiatan pengolahan lahan pertanian [6]. Pemanfaatan adanya teknologi di bidang pertanian ini dapat menjadi faktor penting untuk kegiatan pengembangan di sektor pangan saat ini. Selain dapat berguna untuk mengurangi waktu panen, teknologi yang dimaksud ini bisa memberikan kemudahan yang lainnya [7]. Teknologi ini dikenal dengan Internet of Things (IoT).

Internet of Things (IoT) merupakan paradigma baru dengan fungsionalitas yang membuat pengaturan telekomunikasi tanpa kabel (nirkabel) yang modern dan cepat [8]. Teknologi IoT dapat menghubungkan suatu peralatan tertentu dengan pemanfaatan internet guna menjalankan suatu kegiatan tertentu atau berbagai fungsi. Proses implementasi suatu perangkat IoT dibuat melalui adanya embedded system (sistem yang tertanam), dan dapat menghemat daya [9].

Banyak manfaat yang bisa didapat dari penggunaan IoT di bidang pertanian. Misalnya, dalam pemantauan dan pengelolaan kualitas air dan tanah secara efisien dengan menggunakan Wireless Sensor Network berbasis Internet of Things [10]. Selain itu, penerapan IoT juga banyak digunakan dalam pengelolaan tanaman hidroponik khususnya untuk melakukan kendali nutrisi [11]. Pada sistem tanaman hidroponik juga memerlukan kebutuhan volume air yang sesuai dengan standard yang ditentukan dan dapat diatasi dengan penerapan sistem IoT [12]. Suhu dan kelembaban lingkungan juga harus diperhatikan dan disesuaikan dengan kebutuhan pada tanaman pertanian [13].

Berkembangnya teknologi IoT ini juga dapat memberikan perubahan bidang pertanian khususnya pada sistem irigasi untuk tanaman pertanian [14]. Penerapan IoT menjadi solusi teknologi yang sangat dibutuhkan dengan efisiensi biaya pengembangan yang dapat disesuaikan [15]. IoT di bidang pertanian dapat juga diatur sedemikian rupa untuk proses pengaturan suhu, kelembaban tanah, dan tingkat kecerahan pada saat pertumbuhan tanaman [16].

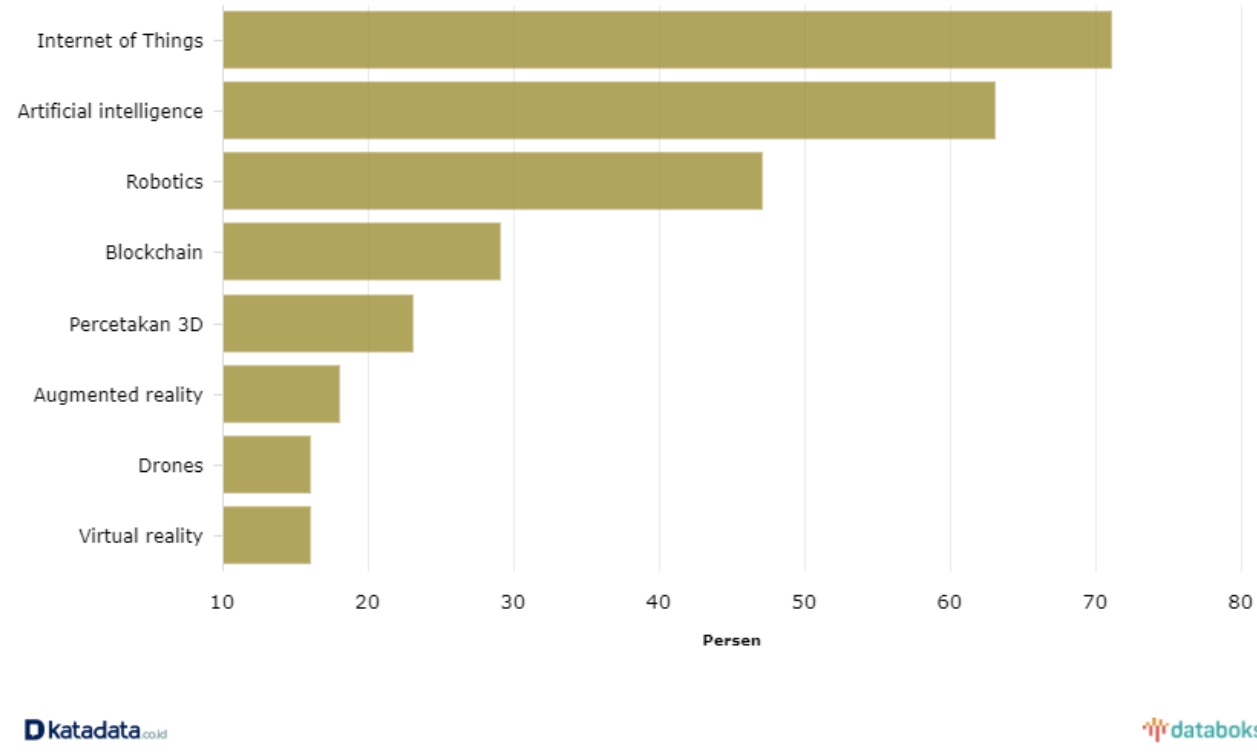

Gambar 1. Teknologi Penting untuk Generasi Penerus Bisnis Keluarga 
Sumber: https://databoks.katadata.co.id

IoT menjadi teknologi yang penting untuk generasi penerus saat ini (lihat Gambar 1). Penerapan IoT akan sangat masif digunakan untuk merealisasikan sistem pertanian cerdas (smart farming). Nantinya, sektor pertanian menjadi bagian dari sektor yang akan memiliki potensi yang besar guna memperoleh manfaat yang banyak dengan penerapan IoT [17].

Dikarenakan populernya penerapan IoT di bidang pertanian saat ini, maka tujuan dari literature review ini yaitu untuk menjelaskan tentang penggunaan Internet of Things (IoT) di bidang pertanian khususnya dalam merealisasikan sistem informasi cerdas pertanian. Dari kegiatan ini diharapkan dapat diketahui hal-hal yang telah diteliti dan halhal yang dapat dikembangkan selanjutnya berkaitan dengan IoT di bidang pertanian.

Berdasarkan penjelesan di atas, maka dapat dirumuskan permasalahannya yaitu bagaimana pemanfaatan sistem informasi cerdas pertanian berbasis Internet of Things (IoT).

\section{TINJAUAN PUSTAKA}

\subsection{Pertanian}

Pertanian adalah suatu cara atau kegiatan untuk memenuhi dan mencukupi kebutuhan pangan [1]. Kegiatan pertanian dilakukan oleh seorang petani dan pekebun yang memiliki tugas untuk membajak, memberikan pupuk dan mengairi lahan pertanian, menghalau adanya hama, memantau kebutuhan air untuk tanaman serta mengatur tingkat kesuburan pada tanah [3]. Pertanian modern sudah mulai menerapkan suatu teknologi untuk meningkatkan produktivitas, memberikan kemudahan untuk petani dalam bekerja, dan ini dikenal dengan istilah pertanian presisi. Pertanian presisi merupakan suatu konsep pengelolaan di bidang pertanian berdasarkan pada suatu observasi dan pengukuran beberapa parameter pertanian dengan presisi yang hasilnya dapat dimanfaatkan sebagai bahan acuan dalam melakukan penanganan pertanian dengan cepat dan tepat [18].

\subsection{Internet of Things (IoT)}

Internet of Things (IoT) adalah suatu teknologi yang berguna untuk memantau suatu perangkat keras (hardware) dan digerakkan dari jarak yang jauh dengan memanfaatkan teknologi komunikasi jaringan internet [19]. Teknologi IoT dapat menjadi jembatan ketidakseimbangan di antara perangkat fisik dan informasi, sebagaimana pengolahan data yang didapatkan dari perangkat eletronik melalui sebuah (interface) antara pengguna sistem dan perangkat IoT [8].

Konsep yang dibangun dari Internet of Things terkait dengan sebuah jaringan, yang menghubungkan berbagai perangkat atau alat dengan internet melalui Radio Frequency Identification (RFID), sensor, global positioning systems (GPS), laser scanner dan sensor informasi lainnya menurut protokol yang telah disetujui dan pertukaran informasi yang mendapatkan identifikasi pengetahuan, pelacakan lokasi, monitoring dan manajemen [9]. Penerapan modul IoT lainnya misalnya, dengan sensor tertentu teknologi 
berbasis IoT dapat juga mengatur rentang nilai suhu dan kelembaban yang diinginkan [20].

\section{METODOLOGI PENELITIAN}

Dalam penelitian ini menggunakan metode tinjauan literatur sistematis atau Systematic Literature Review (SLR) yang digunakan untuk pembelajaran dan pemahaman informasi yang terkait dengan tujuan dan pokok pembahasan penelitian. Metode yang digunakan ini mempunyai tiga alur tahapan yang terdiri dari tahapan perencanaan atau planning, tahapan perlakuan atau conducting, dan tahapan pelaporan atau reporting. Pada tahapan perencanaan, akan ditentukan konteks pencarian artikel, penentuan pertanyaan penelitian (Research Question) yang akan digunakan sebagai dasar dalam perlakuan studi literatur. Tahapan selanjutnya yaitu mencari bahan referensi atau sumber-sumber literatur (Search Process). Dan tahapan yang paling akhir yaitu pelaporan, serta penyimpulan hasil dari penelitian dan kegiatan diskusi yang diajukan.

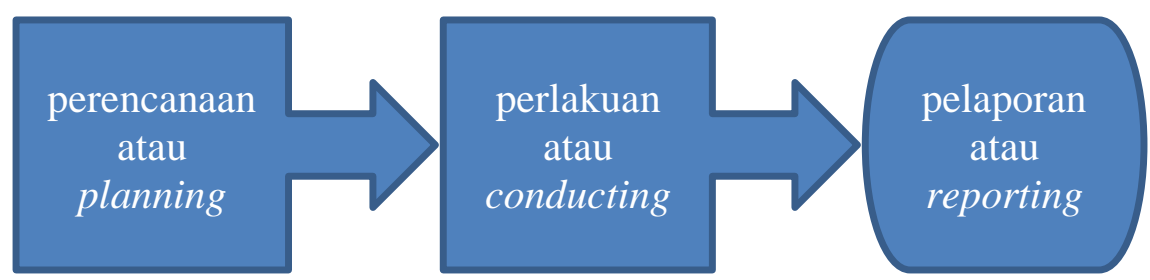

Gambar 2. Alur penelitian Systematic Literature Review

\subsection{Pertanyaan Penelitian (Research Question)}

Daftar pertanyaan penelitian dapat dibuat dari kebutuhan penelitian pada topik yang dibahas. Berikut ini adalah daftar pertanyaan penelitian dalam Literature Review ini:

a) RQ1: Apa saja yang menjadi objek penelitian pada artikel terkait?

b) RQ2: Apa saja metode pengembangan yang digunakan dalam pemanfaatan IoT di bidang pertanian?

c) RQ3: Variabel apa saja yang digunakan dalam pemanfaatan IoT di bidang pertanian?

d) RQ4: Pada platform apa saja sistem pertanian cerdas berbasis IoT dapat dijalankan?

e) RQ5: Dalam kegiatan apa saja Internet of Things sering digunakan di bidang pertanian?

\subsection{Proses Pencarian (Search Process)}

Proses pencarian artikel ilmiah pada Literature Review ini yaitu pencarian database dari Google Scholar melalui software Harzing's Publish or Perish. Kata kunci yang digunakan dalam pencarian artikel ilmiah terkait adalah "IoT" dan "pertanian". Hasil yang didapat berupa 994 artikel dengan rentang waktu publikasi antara tahun 1981-2020. 


\begin{tabular}{lr} 
Publication years: & $1981-2020$ \\
Citation years: & $40(1981-2021)$ \\
Papers: & 994 \\
Citations: & 2280 \\
Cites/year: & 57.00 \\
Cites/paper: & 2.29 \\
Authors/paper: & 2.08 \\
h-index: & 18 \\
g-index: & 41 \\
hI,norm: & 13 \\
hI, annual: & 0.33 \\
Papers with ACC $>=1,2,5,10,20:$ \\
\multicolumn{2}{c}{$158,64,23,12,6$}
\end{tabular}

Gambar 3. Proses Pencarian Artikel Ilmiah

Selanjutnya, penentuan kriteria inklusi (Inclusion Criteria) guna menentukan kelayakan artikel ilmiah untuk diulas maupun tidak. Studi kelayakan artikel terpilih sebagai berikut:

1) Artikel yang digunakan berkaitan dengan topik penelitian mengenai penerapan IoT di bidang pertanian.

2) Semua artikel ilmiah yang diterbitkan dalam Bahasa Indonesia ataupun Bahasa Inggris.

3) Semua artikel ilmiah dapat diakses materinya secara utuh (full PDF).

4) Artikel yang diterbitkan dalam rentang waktu 1 dekade terakhir.

\subsection{Penilaian Kualitas (Quality Assesment)}

Dalam penelitian ini, data hasil Literature Review yang ditemukan akan dievaluasi berdasarkan pertanyaan kriteria penilaian kualitas sebagai berikut:

a) QA1: Apakah artikel ilmiah yang dipilih diterbitkan dalam rentang waktu 2010-2020?

b) QA2: Apakah pada artikel ilmiah yang dipilih menuliskan objek penelitian dalam pemanfaatan IoT di bidang pertanian?

c) QA3: Apakah pada artikel ilmiah yang dipilih menuliskan metode pengembangan penelitian dalam pemanfaatan IoT di bidang pertanian?

d) QA4: Apakah artikel ilmiah menuliskan pemanfaatan IoT di bidang pertanian secara spesifik?

Dari masing-masing artikel ilmiah pilihan, akan diberikan penilaian jawaban di bawah ini untuk tiap-tiap pertanyaan di atas:

a) QA1: Apakah artikel ilmiah yang dipilih diterbitkan dalam rentang waktu 2010-2020? (Ya(2)/Sebagian(1)/Tidak(0))

b) QA2: Apakah pada artikel ilmiah yang dipilih menuliskan objek penelitian dalam pemanfaatan IoT di bidang pertanian? (Ya(2)/Sebagian(1)/Tidak(0)) 
c) QA3: Apakah pada artikel ilmiah yang dipilih menuliskan metode pengembangan penelitian dalam pemanfaatan IoT di bidang pertanian? (Ya(2)/Sebagian(1)/Tidak(0))

d) QA4: Apakah artikel ilmiah menuliskan pemanfaatan IoT di bidang pertanian secara spesifik? (Ya(2)/Sebagian(1)/Tidak(0))

\section{HASIL DAN PEMBAHASAN}

\subsection{Hasil}

Setelah proses perencanaan dan pemilahan, artikel ilmiah yang digunakan hanya berjumlah 20 artikel saja yang sesuai melalui studi kelayakan dan kesesuaian kriteria inklusi. Selanjutnya, dilakukan proses penilaian kualitas artikel ilmiah yang diulas. Berikut ini tabel penilaiannya:

Tabel 1. Penilaian Kualitas Artikel Ilmiah

\begin{tabular}{|c|c|c|c|c|c|c|c|}
\hline Penulis & Judul & Nama Jurnal & QA1 & QA2 & QA3 & QA4 & Nilai \\
\hline $\begin{array}{c}\text { Engel, Ventje } \\
\text { Jeremias Lewi; } \\
\text { Angela, Dina; } \\
\text { Suakanto, } \\
\text { Sinung; } \\
\text { Hutagalung, } \\
\text { Maclaurin. }\end{array}$ & $\begin{array}{c}\text { Model inferensi } \\
\text { konteks internet of } \\
\text { things pada sistem } \\
\text { pertanian cerdas. } \\
{[6]}\end{array}$ & $\begin{array}{c}\text { Jurnal } \\
\text { Telematika, } \\
\text { 11(2), (2016). }\end{array}$ & $Y$ & $Y$ & $Y$ & $Y$ & 8 \\
\hline $\begin{array}{l}\text { Syafiqoh, } \\
\text { Ummi; } \\
\text { Sunardi, } \\
\text { Sunardi; } \\
\text { Yudhana, } \\
\text { Anton. }\end{array}$ & $\begin{array}{c}\text { Pengembangan } \\
\text { Wireless Sensor } \\
\text { Network Berbasis } \\
\text { Internet of Things } \\
\text { untuk Sistem } \\
\text { Pemantauan } \\
\text { Kualitas Air dan } \\
\text { Tanah Pertanian. } \\
{[10]}\end{array}$ & $\begin{array}{c}\text { Jurnal } \\
\text { Informatika: } \\
\text { Jurnal } \\
\text { Pengembangan } \\
\text { IT, 3(2), (2018). }\end{array}$ & $\mathrm{Y}$ & $\mathrm{Y}$ & $Y$ & $\mathrm{Y}$ & 8 \\
\hline $\begin{array}{c}\text { Ulum, } \\
\text { Muhamad } \\
\text { Bahrul. }\end{array}$ & $\begin{array}{c}\text { Desain Internet Of } \\
\text { Things (IoT) Untuk } \\
\text { Optimasi Produksi } \\
\text { Pada Agroindustri } \\
\text { Karet. [8] }\end{array}$ & $\begin{array}{l}\text { Sebatik, 22(2), } \\
\text { (2018). }\end{array}$ & $Y$ & $\mathrm{Y}$ & $Y$ & $\mathrm{Y}$ & 8 \\
\hline $\begin{array}{l}\text { Komaludin, } \\
\text { Deden. }\end{array}$ & $\begin{array}{c}\text { Penerapan } \\
\text { Teknologi Internet } \\
\text { of Thing (IoT) pada } \\
\text { bisnis budidaya } \\
\text { tanaman } \\
\text { Hidroponik sebagai } \\
\text { langkah efisiensi } \\
\text { biaya perawatan. } \\
\text { [9] }\end{array}$ & $\begin{array}{c}\text { Prosiding } \\
\text { FRIMA (Festival } \\
\text { Riset Ilmiah } \\
\text { Manajemen dan } \\
\text { Akuntansi), -(2), } \\
\text { (2018). }\end{array}$ & $\mathrm{Y}$ & $\mathrm{Y}$ & $Y$ & $\mathrm{Y}$ & 8 \\
\hline $\begin{array}{l}\text { Herman, } \\
\text { Herman; } \\
\text { Adidrana, }\end{array}$ & $\begin{array}{c}\text { Hydroponic } \\
\text { Nutrient Control } \\
\text { System Based on }\end{array}$ & $\begin{array}{c}\text { CommIT } \\
\text { (Communication } \\
\text { and Information }\end{array}$ & $Y$ & $Y$ & Y & $Y$ & 8 \\
\hline
\end{tabular}




\begin{tabular}{|c|c|c|c|c|c|c|c|}
\hline $\begin{array}{c}\text { Demi; } \\
\text { Surantha, } \\
\text { Nico; } \\
\text { Suharjito, } \\
\text { Suharjito. }\end{array}$ & $\begin{array}{c}\text { Internet of Things. } \\
{[11]}\end{array}$ & $\begin{array}{c}\text { Technology) } \\
\text { Journal, 13(2), } \\
\text { (2019). }\end{array}$ & & & & & \\
\hline $\begin{array}{l}\text { Sukmana, } \\
\text { Septian } \\
\text { Enggar; } \\
\text { Winarsih, } \\
\text { Nurul Anisa } \\
\text { Sri; Akbar, } \\
\text { Akmaludin. }\end{array}$ & $\begin{array}{c}\text { Sliding Modes } \\
\text { Strategy } \\
\text { Implementation for } \\
\text { Controlling } \\
\text { Nutrition in } \\
\text { Hydroponics Based } \\
\text { IoT. }[15]\end{array}$ & $\begin{array}{l}\text { Journal of } \\
\text { Applied } \\
\text { Intelligent } \\
\text { System, 4(2), } \\
\text { (2019). }\end{array}$ & $\mathrm{Y}$ & $Y$ & $\mathrm{Y}$ & $\mathrm{Y}$ & 8 \\
\hline $\begin{array}{l}\text { Ayudyana, } \\
\text { Vines. }\end{array}$ & $\begin{array}{c}\text { Rancang Bangun } \\
\text { Sistem } \\
\text { Pengontrolan pH } \\
\text { Larutan untuk } \\
\text { Budidaya Tanaman } \\
\text { Hidroponik } \\
\text { Berbasis Internet of } \\
\text { Things. [1] }\end{array}$ & $\begin{array}{c}\text { PILLAR OF } \\
\text { PHYSICS, 12(2), } \\
\text { (2019). }\end{array}$ & $Y$ & $\mathrm{Y}$ & $Y$ & $\mathrm{Y}$ & 8 \\
\hline $\begin{array}{l}\text { Sumarudin, A; } \\
\text { Putra, Willy } \\
\text { Permana; } \\
\text { Ismantohadi, } \\
\text { Eka; Supardi, } \\
\text { Supardi; } \\
\text { Qomarrudin, } \\
\text { Muhammad. }\end{array}$ & $\begin{array}{c}\text { Sistem Monitoring } \\
\text { Tanaman } \\
\text { Hortikultura } \\
\text { Pertanian di } \\
\text { Kabupaten } \\
\text { Indramayu } \\
\text { Berbasis Internet of } \\
\text { Thing. [3] }\end{array}$ & $\begin{array}{c}\text { Jurnal } \\
\text { Teknologi dan } \\
\text { Informasi } \\
(J A T I), 9(1), \\
\text { (2019). }\end{array}$ & $\mathrm{Y}$ & $\mathrm{Y}$ & $\mathrm{Y}$ & $\mathrm{Y}$ & 8 \\
\hline $\begin{array}{c}\text { Husdi, Husdi; } \\
\text { Lasena, } \\
\text { Yulianty. }\end{array}$ & $\begin{array}{c}\text { Real Time Analisys } \\
\text { Berbasis Internet Of } \\
\text { Things Untuk } \\
\text { Prediksi Iklim } \\
\text { Lahan Pertanian. } \\
\text { [5] }\end{array}$ & $\begin{array}{c}\text { JURNAL } \\
\text { MEDIA } \\
\text { INFORMATIKA } \\
\text { BUDIDARMA, } \\
\text { 4(3), (2020). }\end{array}$ & $\mathrm{Y}$ & $\mathrm{Y}$ & $\mathrm{Y}$ & $Y$ & 8 \\
\hline $\begin{array}{c}\text { Putra, } \\
\text { Chrystia Aji; } \\
\text { Puspaningrum, } \\
\text { Eva Yulia. }\end{array}$ & $\begin{array}{l}\text { Pengendalian dan } \\
\text { Pemantauan Air } \\
\text { pada Sistem } \\
\text { Hidroponik dengan } \\
\text { Memanfaatkan } \\
\text { Internet of Things } \\
\text { (IoT). [12] }\end{array}$ & $\begin{array}{c}\text { Prosiding } \\
\text { Seminar } \\
\text { Nasional } \\
\text { Informatika Bela } \\
\text { Negara, 1(-), } \\
\text { (2020). }\end{array}$ & $\mathrm{Y}$ & $\mathrm{Y}$ & $\mathrm{Y}$ & $\mathrm{Y}$ & 8 \\
\hline $\begin{array}{c}\text { Roihan, A.; } \\
\text { Hasanudin, } \\
\text { M.; Sunandar, } \\
\text { E.; Pratama, S. } \\
\text { R. }\end{array}$ & $\begin{array}{c}\text { Perancangan } \\
\text { Purwarupa Bird } \\
\text { Repellent Device } \\
\text { sebagai Optimasi } \\
\text { Panen Padi di } \\
\text { Bidang Pertanian } \\
\text { Berbasis Internet Of } \\
\text { Things. [7] }\end{array}$ & $\begin{array}{c}\text { Simetris: Jurnal } \\
\text { Teknik Mesin, } \\
\text { Elektro dan Ilmu } \\
\text { Komputer, 11(1), } \\
\text { (2020). }\end{array}$ & $\mathrm{Y}$ & $\mathrm{Y}$ & $\mathrm{Y}$ & $\mathrm{Y}$ & 8 \\
\hline
\end{tabular}




\begin{tabular}{|c|c|c|c|c|c|c|c|}
\hline $\begin{array}{c}\text { Hidayat, Hari } \\
\text { Toha; Akhyar, } \\
\text { Akhyar; } \\
\text { Mahdi, Mahdi; }\end{array}$ & $\begin{array}{l}\text { Rancang Bangun } \\
\text { Prototipe Pengusir } \\
\text { Hama Tikus dan } \\
\text { Burung Berbasis } \\
\text { Internet of Things } \\
\text { (IoT) [4] }\end{array}$ & $\begin{array}{c}\text { Prosiding } \\
\text { Seminar } \\
\text { Nasional } \\
\text { Politeknik } \\
\text { Negeri } \\
\text { Lhokseumawe, } \\
\text { 3(1), (2019). }\end{array}$ & $\mathrm{Y}$ & $\mathrm{Y}$ & $\mathrm{Y}$ & $\mathrm{Y}$ & 8 \\
\hline $\begin{array}{c}\text { Data, M; } \\
\text { Yahya, W; } \\
\text { Kurniawan, A. }\end{array}$ & $\begin{array}{c}\text { Implementasi } \\
\text { Teknologi } \\
\text { Virtualisasi } \\
\text { Berbasis Kontainer } \\
\text { untuk Perangkat } \\
\text { Internet of Things } \\
\text { pada Pertanian } \\
\text { Presisi [18] }\end{array}$ & $\begin{array}{c}\text { CYBERNETICS, } \\
\text { 3(1), (2020). }\end{array}$ & $\mathrm{Y}$ & $\mathrm{Y}$ & $Y$ & $\mathrm{Y}$ & 8 \\
\hline Alam, E N. & $\begin{array}{c}\text { IoT in Agriculture } \\
\text { Industry [17] }\end{array}$ & $\begin{array}{c}\text { Jurnal Sistem } \\
\text { Cerdas, (2020). }\end{array}$ & $\mathrm{Y}$ & $\mathrm{Y}$ & $\mathrm{Y}$ & $X$ & 6 \\
\hline $\begin{array}{l}\text { Visenno, T; } \\
\text { Fath, N. }\end{array}$ & $\begin{array}{c}\text { MONITORING } \\
\text { SISTEM } \\
\text { KELEMBAPAN } \\
\text { TANAH PADA } \\
\text { TANAMAN } \\
\text { TOMAT } \\
\text { BERBASIS IOT } \\
\text { (Internet Of } \\
\text { Things) [2] }\end{array}$ & $\begin{array}{l}\text { MAESTRO, } \\
\text { 3(1), (2020). }\end{array}$ & $\mathrm{Y}$ & $\mathrm{Y}$ & $Y$ & $\mathrm{Y}$ & 8 \\
\hline $\begin{array}{c}\text { Fitriawan, } \\
\text { Helmy; } \\
\text { Cahyo, Kholid } \\
\text { Ali Dwi; } \\
\text { Purwiyanti, } \\
\text { Sri; } \\
\text { Alam, Syaiful; }\end{array}$ & $\begin{array}{c}\text { PENGENDALIAN } \\
\text { SUHU DAN } \\
\text { KELEMBABAN } \\
\text { PADA BUDIDAYA } \\
\text { JAMUR TIRAM } \\
\text { BERBASIS IoT } \\
{[20]}\end{array}$ & $\begin{array}{c}\text { Jurnal Teknik } \\
\text { Pertanian } \\
\text { Lampung, 9(1), } \\
\text { (2020). }\end{array}$ & $\mathrm{Y}$ & $Y$ & $\mathrm{Y}$ & $Y$ & 8 \\
\hline $\begin{array}{c}\text { Nalendra, A K; } \\
\text { Mujiono, M. }\end{array}$ & $\begin{array}{c}\text { Perancangan IoT } \\
\text { (Internet of Things) } \\
\text { pada Sistem Irigasi } \\
\text { Tanaman Cabai } \\
{[14]}\end{array}$ & $\begin{array}{c}\text { Generation } \\
\text { Journal, 4(2), } \\
(2020) .\end{array}$ & $Y$ & $\mathrm{Y}$ & $\mathrm{Y}$ & $\mathrm{Y}$ & 8 \\
\hline $\begin{array}{c}\text { Minariyanto, } \\
\text { A; Mardiono, } \\
\text { M; Lestari, S } \\
\text { W. }\end{array}$ & $\begin{array}{c}\text { Perancangan } \\
\text { Prototype Sistem } \\
\text { Pengendali } \\
\text { Otomatis Pada } \\
\text { Greenhouse } \\
\text { Untuk Tanaman } \\
\text { Cabai Berbasis } \\
\text { Arduino Dan } \\
\text { Internet Of Things } \\
\text { (IoT) [13] }\end{array}$ & $\begin{array}{c}\text { Jurnal } \\
\text { Teknologi, 7(2), } \\
(\mathbf{2 0 2 0}) .\end{array}$ & $\mathrm{Y}$ & $\mathrm{Y}$ & $\mathrm{Y}$ & $\mathrm{Y}$ & 8 \\
\hline
\end{tabular}




\begin{tabular}{|c|c|c|c|c|c|c|c|}
\hline $\begin{array}{c}\text { Sasmoko, } \\
\text { Dani; Horman, } \\
\text { Rena. }\end{array}$ & $\begin{array}{c}\text { Sistem Monitoring } \\
\text { Aliran Air Dan } \\
\text { Penyiraman } \\
\text { Otomatis Pada } \\
\text { Rumah Kaca } \\
\text { Berbasis IOT } \\
\text { Dengan Esp8266 } \\
\text { Dan Blynk. [19] }\end{array}$ & $\begin{array}{c}\text { CIRCUIT: } \\
\text { Jurnal Ilmiah } \\
\text { Pendidikan } \\
\text { Teknik Elektro, } \\
\text { 4(1), (2020) }\end{array}$ & $\mathrm{Y}$ & $\mathrm{Y}$ & $\mathrm{Y}$ & $\mathrm{Y}$ & 8 \\
\hline Doni, R; & $\begin{array}{c}\text { Sistem Monitoring } \\
\text { Tanaman } \\
\text { Rahman, M. }\end{array}$ & $\begin{array}{c}\text { J-SAKTI (Jurnal } \\
\text { Sains Komputer } \\
\text { dan } \\
\text { Berbasis Iot } \\
\text { (Internet of Thing) } \\
\text { Menggunakan } \\
\text { Nodemcu ESP8266. } \\
\text { Informatika), }\end{array}$ & Y(2), (2020). & Y & Y & Y & 8 \\
\hline
\end{tabular}

Keterangan: $(\mathrm{Ya}=2 /$ Sebagian $=1 /$ Tidak $=0)$

Total Nilai $=158$ dari total nilai sempurna 160. Prosentase Nilai $=$ $(158 / 160) * 100 \%=98,75 \%$; artinya artikel ilmiah yang diulas sudah sesuai kebutuhan berdasarkan Penilaian Kualitas Artikel Ilmiah.

\subsection{Pembahasan}

Pada bagian ini akan memaparkan penjelasan dari pertanyaan penelitian (Research Question) yang telah ditentukan.

a) RQ1: Apa saja yang menjadi objek penelitian pada artikel terkait?

Objek penelitian pada pemanfaatan IoT di bidang pertanian pada artikel ilmiah terpilih ditunjukkan pada grafik berikut ini:

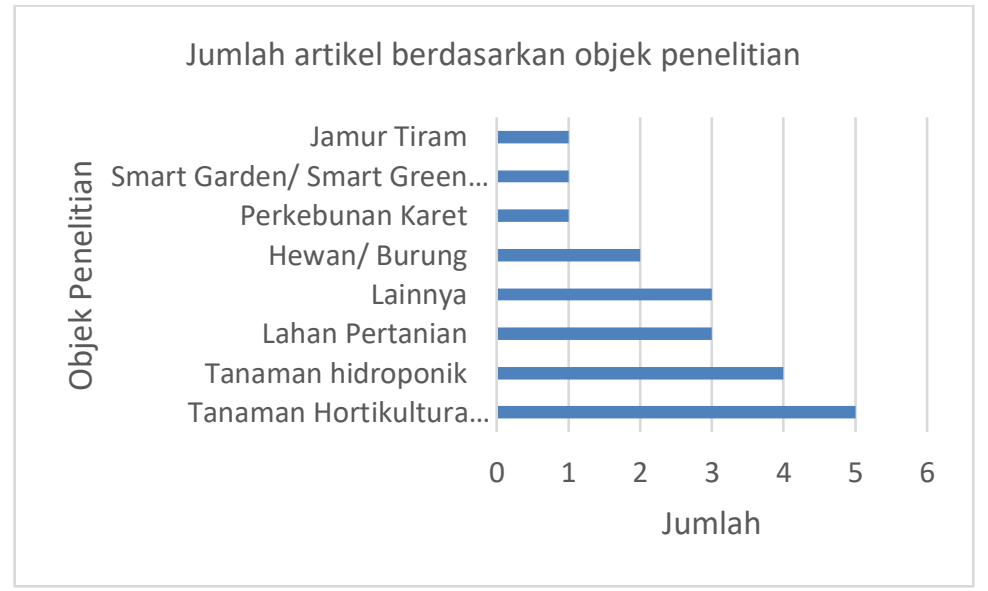

Gambar 4. Jumlah artikel berdasarkan objek penelitian

Dari grafik di atas, dapat dilihat bahwa objek penelitian yang paling banyak digunakan yaitu pada tanaman hortikultura. Penerapan IoT pada sistem pertanian tanaman hortikultura dibahas di 5 artikel. Tanaman Hortikultura tersebut diantaranya berupa bawang merah, cabai, tomat, ataupun selada. Objek penelitian terbanyak kedua yaitu pada budidaya hidroponik yang terdapat pada 4 artikel. Sedangkan, sisanya menggunakan objek penelitian yang berbeda-beda. 
b) RQ2: Apa saja metode pengembangan yang digunakan dalam pemanfaatan IoT di bidang pertanian?

Penggunaan metode pengembangan dalam pemanfaatan IoT di bidang pertanian ditunjukkan pada grafik berikut ini:

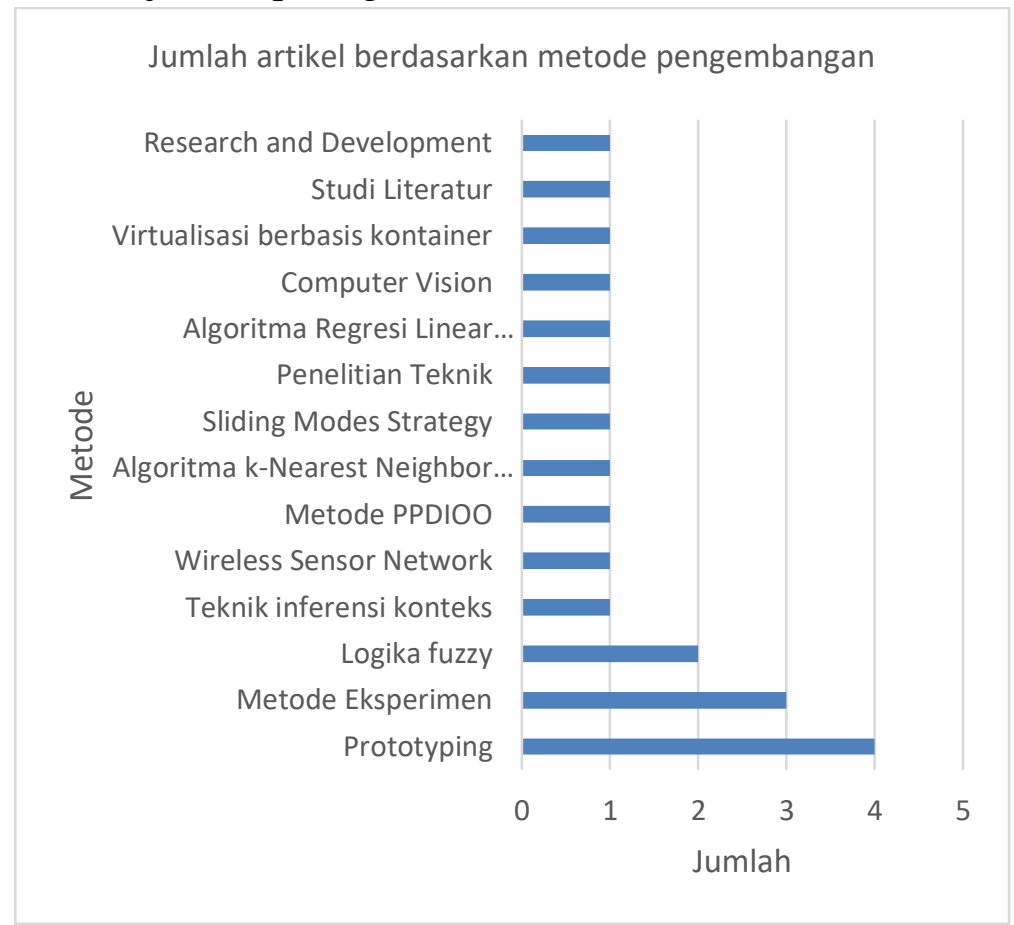

Gambar 5. Jumlah artikel berdasarkan metode pengembangan

Ada sekitar 14 metode pengembangan yang digunakan dalam pemanfaatan IoT di bidang pertanian ini. Metode terbanyak digunakan yaitu metode prototyping sebanyak 4 artikel yang membahas. Pada artikel tersebut dibahas mengenai bagaimana perancangan dan pembuatan prototype dari sistem pertanian cerdas berbasis IoT yang diteliti. Sebagai contoh artikel yang menerapakan metode ini yaitu artikel dengan judul "Perancangan Prototype Sistem Pengendali Otomatis Pada Greenhouse Untuk Tanaman Cabai Berbasis Arduino dan Internet Of Things (IoT)". Metode pengembangan kedua yaitu metode eksperimen sebanyak 3 artikel. Selanjutnya, metode logika fuzzy sebanyak 2 artikel. Dan, sisanya metode lain-lain yang berbeda.

c) RQ3: Variabel apa saja yang digunakan dalam pemanfaatan IoT di bidang pertanian?

Pemilihan variabel penilitian dalam pemanfaatan IoT di bidang pertanian pada artikel ilmiah terpilih ditunjukkan pada grafik berikut ini: 


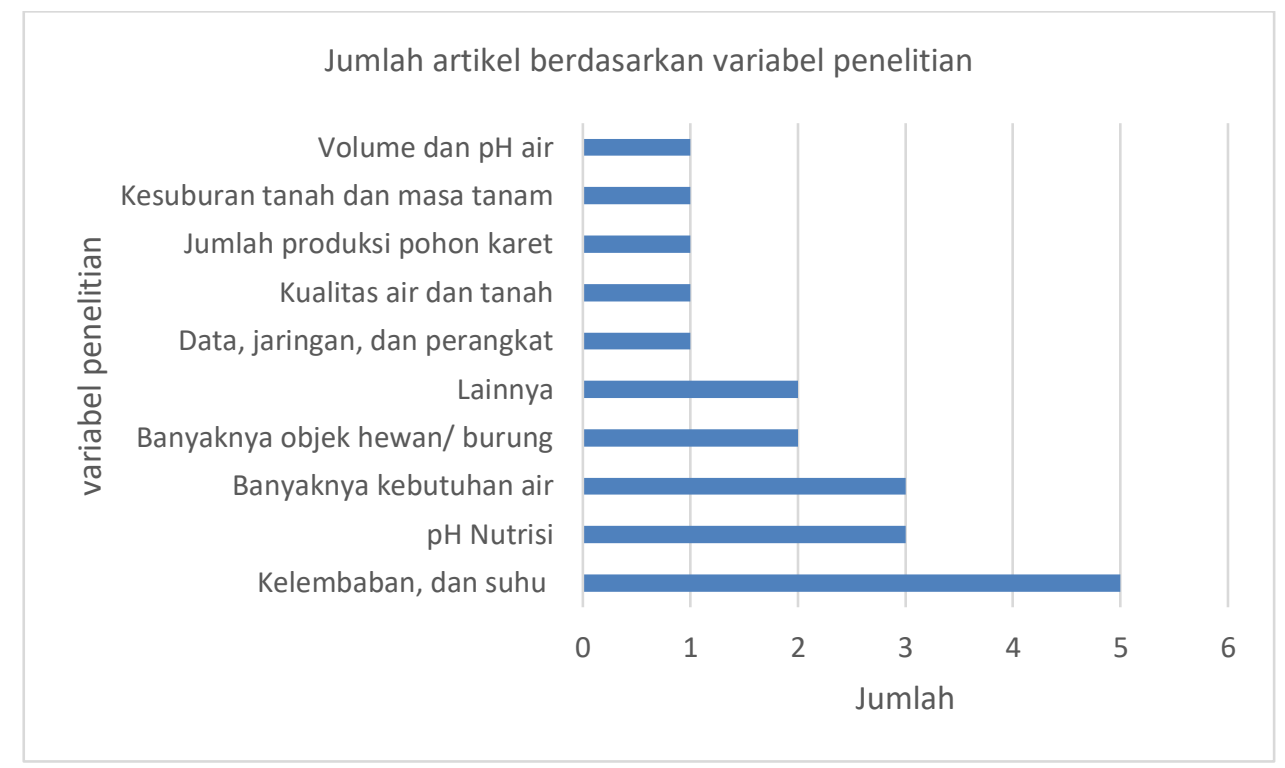

Gambar 6. Jumlah artikel berdasarkan variabel penelitian

Ada 10 pengelompokan variabel penelitian yang terangkum dari artikel ilmiah terpilih. Variabel penelitian yang paling banyak diteliti yaitu pada kelembapan, dan suhu baik yang di tanah, air, maupun udara dengan jumlah artikel sebanyak 5. Variabel lainnya yaitu pH Nutrisi tanaman, dan banyaknya kebutuhan air pada tanaman yang di bahas di masing-masing 3 artikel. Sisanya adalah variabel penelitian yang berbeda-beda seperti banyaknya hewan atau burung, lainnya, data perangkat, kualitas air tanah, jumlah produksi, kesuburan tanah dan masa tanam, serta volume dan $\mathrm{pH}$ air.

d) RQ4: Pada platform apa saja sistem pertanian cerdas berbasis IoT dapat dijalankan?

Ada setidaknya 3 platform utama yang digunakan dalam Sistem Informasi Cerdas Pertanian Berbasis Internet of Things (IoT) yaitu website, android, dan desktop. Dalam beberapa artikel lainnya ada juga yang tidak diketahui platform apa yang digunakan. Dari beberapa platform, website berbasis IoT adalah platform yang terbanyak digunakan dan dijelaskan di 8 artikel. Salah satu contoh penelitian yang menggunakan platform web adalah penelitian dengan judul "Real Time Analisys Berbasis Internet Of Things Untuk Prediksi Iklim Lahan Pertanian". Penelitian tersebut telah menghasilkan karya sistem pertanian cerdas berbasis Internet of Things (IoT) dengan nama Aplikasi Web E-SmartFarm. Platform yang banyak digunakan lainnya yaitu aplikasi mobile atau android berbasis IoT yang dijelaskan di 5 artikel. Dan, lainnya adalah Wireless Sensor Network berbasis (IoT) dan PC atau Desktop komputer. Berikut ini grafik penggunaan platform dalam pemanfaatan IoT di bidang pertanian: 


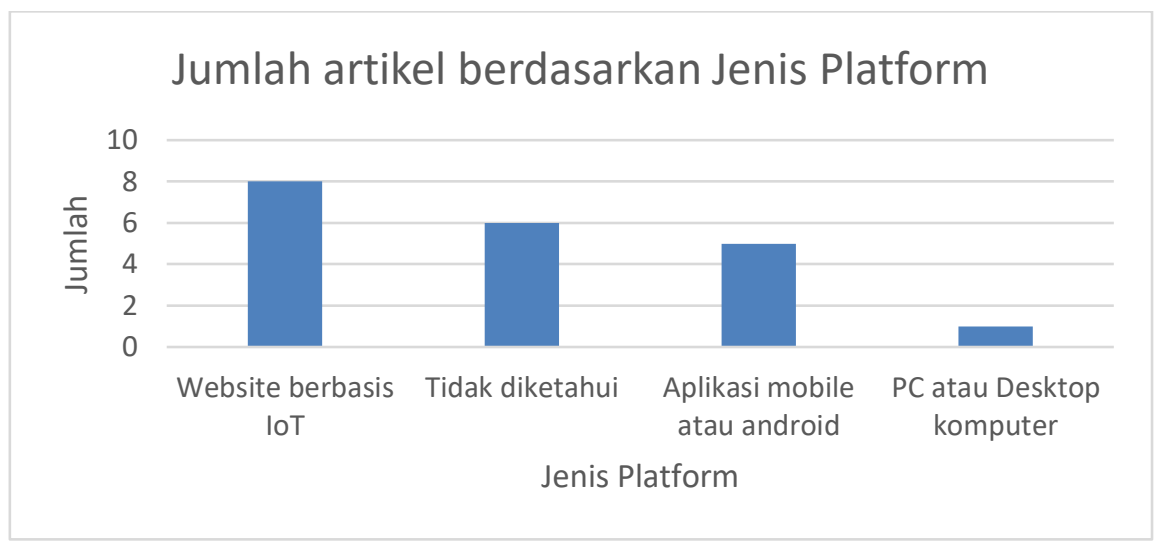

Gambar 7. Jumlah artikel berdasarkan Jenis Platform

e) RQ5: Dalam kegiatan apa saja Internet of Things sering digunakan di bidang pertanian?

Pemanfaatan IoT di bidang pertanian lebih banyak diaplikasikan untuk efisiensi biaya perawatan dan pengelolaan tanaman. IoT dipergunakan untuk pengendalian-pengendalian mulai dari pengaturan $\mathrm{pH}$ nutrisi tanaman, $\mathrm{pH}$ air, pengaturan banyaknya kebutuhan air, pembacaan objek hewan burung atau hama tikus di sawah, dan untuk kegunaan yang lainnya.

\section{KESIMPULAN}

Dari beberapa artikel ilmiah yang telah diulas, dapat disimpulkan bahwa secara umum literatur review ini menunjukkan bahwa yang banyak dilakukan dalam pemanfaatan IoT di bidang pertanian yaitu Penerapan IoT pada sistem pertanian tanaman hortikultura yang dibahas di 5 artikel. Metode pengembangan terbanyak digunakan yaitu metode prototyping sebanyak 4 artikel yang membahas. Variabel penelitian yang paling banyak diteliti yaitu pada kelembapan, dan suhu baik yang di tanah, air, maupun udara dengan jumlah artikel sebanyak 5. Dan, website berbasis IoT adalah platform yang terbanyak digunakan dan dijelaskan di 8 artikel.

Untuk pembahasan literatur review terkait pemanfaatan IoT di bidang pertanian kedepannya dapat diperbanyak lagi bahan referensi artikel ilmiah yang dibahas. Dan, untuk pengembangan IoT mendatang dapat menggunakan platform mobile karena perkembangannya yang begitu cepat dalam 1 dekade terakhir.

\section{DAFTAR PUSTAKA}

[1] V. Ayudyana, "Rancang Bangun Sistem Pengontrolan pH Larutan untuk Budidaya Tanaman Hidroponik Berbasis Internet of Things," PILLAR Phys., vol. 12, no. 2, 2019.

[2] T. Visenno and N. Fath, "MONITORING SISTEM KELEMBAPAN TANAH PADA TANAMAN TOMAT BERBASIS IOT (Internet Of Things), " MAESTRO, vol. 3, no. 1, pp. 107-115, 2020.

[3] A. Sumarudin, W. P. Putra, E. Ismantohadi, S. Supardi, and M. Qomarrudin, 
"Sistem Monitoring Tanaman Hortikultura Pertanian di Kabupaten Indramayu Berbasis Internet Of Things," J. Teknol. dan Inf., vol. 9, no. 1, pp. 45-54, 2019.

[4] H. T. Hidayat, A. Akhyar, and M. Mahdi, "Rancang Bangun Prototipe Pengusir Hama Tikus dan Burung Berbasis Internet of Things (IoT)," Pros. Semin. Nas. Politek. Negeri Lhokseumawe, vol. 3, no. 1, pp. A235-A239, 2019.

[5] H. Husdi and Y. Lasena, "Real Time Analisys Berbasis Internet Of Things Untuk Prediksi Iklim Lahan Pertanian,” J. MEDIA Inform. BUDIDARMA, vol. 4, no. 3, pp. 834-840, 2020.

[6] V. J. L. Engel, D. Angela, S. Suakanto, and M. Hutagalung, "Model inferensi konteks internet of things pada sistem pertanian cerdas," J. Telemat., vol. 11, no. 2, p. 6, 2016.

[7] A. Roihan, M. Hasanudin, E. Sunandar, and S. R. Pratama, "PERANCANGAN PURWARUPA BIRD REPELLENT DEVICE SEBAGAI OPTIMASI PANEN PADI DI BIDANG PERTANIAN BERBASIS INTERNET OF THINGS," Simetris J. Tek. Mesin, Elektro dan Ilmu Komput., vol. 11, no. 1, pp. 129-134, 2020.

[8] M. B. Ulum, "Desain Internet Of Things (IoT) Untuk Optimasi Produksi Pada Agroindustri Karet," Sebatik, vol. 22, no. 2, pp. 69-73, 2018.

[9] D. Komaludin, "Penerapan Teknologi Internet of Thing (IoT) pada bisnis budidaya tanaman Hidroponik sebagai langkah efisiensi biaya perawatan," Pros. FRIMA (Festival Ris. Ilm. Manaj. dan Akuntansi), no. 1, pp. 682-690, 2018.

[10] U. Syafiqoh, S. Sunardi, and A. Yudhana, "Pengembangan Wireless Sensor Network Berbasis Internet of Things untuk Sistem Pemantauan Kualitas Air dan Tanah Pertanian,” J. Inform. J. Pengemb. IT, vol. 3, no. 2, pp. 285-289, 2018.

[11] H. Herman, D. Adidrana, N. Surantha, and S. Suharjito, "Hydroponic Nutrient Control System Based on Internet of Things," CommIT (Communication Inf. Technol. J., vol. 13, no. 2, pp. 105-111, 2019.

[12] C. A. Putra and E. Y. Puspaningrum, "Pengendalian dan Pemantauan Air pada Sistem Hidroponik dengan Memanfaatkan Internet of Things (IoT)," in Prosiding Seminar Nasional Informatika Bela Negara, 2020, vol. 1, pp. 6-9.

[13] A. Minariyanto, M. Mardiono, and S. W. Lestari, "Perancangan Prototype Sistem Pengendali Otomatis Pada Greenhouse Untuk Tanaman Cabai Berbasis Arduino Dan Internet Of Things (IoT)," J. Teknol., vol. 7, no. 2, pp. 120-134, 2020.

[14] A. K. Nalendra and M. Mujiono, "PERANCANGAN IoT (INTERNET OF THINGS) PADA SISTEM IRIGASI TANAMAN CABAI," Gener. J., vol. 4, no. 2, pp. 61-68, 2020.

[15] S. E. Sukmana, N. A. S. Winarsih, and A. Akbar, "Sliding Modes Strategy Implementation for Controlling Nutrition in Hydroponics Based IoT,” J. Appl. Intell. Syst., vol. 4, no. 2, pp. 48-56, 2019.

[16] R. Doni and M. Rahman, "Sistem Monitoring Tanaman Hidroponik Berbasis Iot (Internet of Thing) Menggunakan Nodemcu ESP8266," J-SAKTI (Jurnal Sains Komput. dan Inform., vol. 4, no. 2, pp. 516-522, 2020. 
[17] E. N. Alam, "IoT in Agriculture Industry,” J. Sist. Cerdas, 2020.

[18] M. Data, W. Yahya, and A. Kurniawan, "Implementasi Teknologi Virtualisasi Berbasis Kontainer untuk Perangkat Internet of Things pada Pertanian Presisi," CYBERNETICS, vol. 3, no. 1, pp. 1-7, 2020.

[19] D. Sasmoko and R. Horman, "Sistem Monitoring aliran air dan Penyiraman Otomatis Pada Rumah Kaca Berbasis IoT dengan Esp8266 dan Blynk," CIRCUIT J. Ilm. Pendidik. Tek. Elektro, vol. 4, no. 1, pp. 1-10, 2020.

[20] H. Fitriawan, K. A. D. Cahyo, S. Purwiyanti, and S. Alam, "Pengendalian Suhu dan Kelembaban pada Budidaya Jamur Tiram Berbasis IoT," J. Tek. Pertan. Lampung, vol. 9, no. 1, pp. 28-37, 2020. 